\title{
Coupling relationship between cold chain logistics and economic development: A investigation from China
}

\author{
Ruhe $\mathrm{Xie}^{1}$, Hong Huang $\circledast^{1 *}$, Yuan Zhang ${ }^{1,2}$, Peiyun $\mathrm{Yu}^{3}$ \\ 1 School of Management, Guangzhou University, Guangzhou, China, 2 School of Management, Guizhou \\ University of Commerce, Guiyang, China, 3 School of Management, Guangzhou College of Commerce, \\ Guangzhou, China \\ * Huanghong0929@e.gzhu.edu.cn
}

\section{Abstract}

This paper builds an evaluation index system, uses the entropy weight method (EWM) to decide the weights and, based on the coupling coordination degree model (CCDM), it systematically studies the coupling relationship between Chinese cold chain logistics and the Chinese economy from 2010 to 2019. It performs a grey relational analysis (GRE) to explore the main factors influencing the coordinated development of the two. The results show that the coupling coordination degree between the two presents a steady upward trend, and their coupling relationship has been upgraded from 'coordination' to 'good coordination'. They also indicate that the added value in the tertiary industry, the per capita gross domestic product (GDP), and household consumption levels are the main factors affecting the development of cold chain logistics, while the per capita cold storage capacity, the turnover of road cold chain freight, and the volume of human-power employed in cold chain logistics are the main factors affecting economic development. This study makes suggestions to support the coordinated development of cold chain logistics and economy, and provides a scientific basis for further research.

Accepted: February 11, 2022

Published: February 25, 2022

Peer Review History: PLOS recognizes the benefits of transparency in the peer review process; therefore, we enable the publication of all of the content of peer review and author responses alongside final, published articles. The editorial history of this article is available here: https://doi.org/10.1371/journal.pone.0264561

Copyright: ๑ 2022 Xie et al. This is an open access article distributed under the terms of the Creative Commons Attribution License, which permits unrestricted use, distribution, and reproduction in any medium, provided the original author and source are credited.

Data Availability Statement: All relevant data are within the manuscript and its Supporting Information files.

\section{Introduction}

As the rapid development of the global economy intensifies the process of urbanization, and consumer requirements and expectations regarding the quantity and quality of fresh food continue to rise, cold chain logistics becomes the fundamental prerequisite to fulfilling consumer requirements [1]. The term refers to a systematic process that ensures that refrigerated and frozen food is always stored and transported in an appropriately low-temperature environment at all stages, from production to consumption, to guarantee quality and reduce waste and loss to a minimum [2-4]. According to the report of the China Cold-chain Logistics Association [5], the market demand for cold chain logistics in China increased by $17.5 \%$ in 2019, and the market size is expected to reach RMB 915 billion (US $\$ 140$ billion) in 2025, with an average annual growth rate of $18 \%$ that should provide tremendous potential for the overall increase of the market economy.

It is worth noting that the relationship between cold chain logistics and economic development is becoming increasingly close [6]. The development of the former drives the latter by 
Funding: This research was funded by the National Social Science Foundation of China (grant number 17BJY102).

Competing interests: We have declared that no competing interests exist. allowing macro-economic control, innovating diversified economic development modes, stabilizing prices and farmer income, and guaranteeing food safety [1, 7-9]. In turn, creating and supporting a solid industrial infrastructure, providing ample financial support, stimulating market demand potential, and enhancing industry service professionalization can spur the development of cold chain logistics [10-12]. However, if the overall economic development cannot generate sufficient demand for cold chain logistics capacity, further investment in human, financial, and other resources will only result in a waste of governmental and social resources. Reversely, if the input of government and social resources fails to meet the developmental needs of cold chain logistics, the consequences on the safety of the transported fresh agricultural products and the quality of life of consumers will undermine the overall economic development and the vitality of the sector in particular, as neither will be able to reach its full potential [10]. In other words, cold chain logistics and the economy are very likely to benefit from mutual, combined, coordinated growth, which is the optimal option to maximize the profits of stakeholders. However, current studies mainly focus on the impact of cold chain logistics on the economy, tend to neglect the reverse influence, and fail to further enquire on their coordinated development. Therefore, our research makes important contributions to our understanding of their interaction.

This study analyzes the interaction between Chinese cold chain logistics and the economy. Nowadays, with the help of information technology (e.g., blockchain, Internet of Things, big data, cloud computing, $\mathrm{Al}$ ), cold chain logistics is in a better position to assist suppliers in managing orders, controlling inventory, meeting consumer demand for convenience and timely delivery, and benefit from economies of scale $[6,13,14]$. In terms of benefits generation, economic growth encourages the formation of innovative processes for cold chain logistics to optimize the supply chain, which increases consumer demand for products reliant on cold chain logistics and stimulate further development of the industry.

Therefore, this study revolves around the correlation between cold chain logistics and economic development and examines their coupling relationship. It is important to capture the coordination mechanism among various factors of cold chain logistics and economic development theoretically and empirically and to explore effective methods to measure the two.

This paper aims to build an evaluation framework with an index system that can evaluate the coordinated development level of cold chain logistics and economy, in order to analyze and measure the coupling relationship between cold chain logistics and economic development, to determine the main factors affecting their coordinated development, and to suggest specific measures to enhance their coordination. The paper is structured as follows. Section 2 outlines trends in existing literature on the interaction between cold chain logistics and the economy. Section 3 constructs the index evaluation system and presents the research methods, namely EWM, CCMD, and GRA. Section 4 analyzes the coordinated development of cold chain logistics and the economy. Section 5 proceeds with an analysis and discussion of the influencing factors affecting their coordinated development, and outlines policy recommendations, Section 6 concludes the paper and Section 7 briefly expounds on research limitations and suggests directions for future research.

\section{Literature review}

In an era marked with enormous changes in consumption habits and patterns, scholarly studies focus on the sustainable development of logistics and the economy, but without elaborating specifically on the coordinated development relationship between cold chain logistics and the economy. The metropolitan economy contributes to the increase in demand for logistics and the investment in infrastructure, thus enhancing the coordinated development of the metropolitan economy and logistics $[15,16]$. More significantly, there is a positive interaction between the metropolitan economy and logistics [10]. The global economy and improved living standards have 
diversified the demand for logistics. The development of cold chain meets consumer demand by ensuring timely delivery of a wide range of products, from fresh food delivery to vaccines shipment. Cold chain is an extremely important sector of the logistics industry and has made a substantial contribution to a developing Chinese economy in recent years [1].

Regarding the cold chain logistics operation mode, Liu et al. [17] created a Joint Distribution-Green Vehicle Routing Problem model and concluded that joint distribution in cold chain logistics can balance economic and environmental benefits. Rodrigues et al. [18] analyzed the factors affecting the efficiency of third-party logistics suppliers of refrigeration services in Brazil and made suggestions to tackle challenges in the supply chain to improve company performance. Some scholars considered the relevant technologies to optimize the operation of cold chain logistics. Defraeye et al. [19] suggested ways to optimize the pre-cooling technology for fresh agricultural products before they are placed into refrigerated containers and decrease the heat load in the cold chain logistics chain to reduce energy consumption. Dao et al. [20] studied the insulation materials used for vaccine transport containers and found that the basic algorithm developed to simulate complex heat transfer processes can also be a fast and economical tool for screening suitable phase change materials to reduce transportation costs. Li et al. [21] applied the Internet of things technology to real-time monitoring of safety and quality parameters of perishable products, such as temperature and humidity during transportation, in the cold chain logistics transportation process. Other researchers probed into the influencing factors of cold chain logistics. Zhang et al. [22] discussed the impact of government subsidies towards reducing carbon emissions and relevant trading policies on regional cold chain logistics, and provided suggestions for the government and enterprises to support their joint effort to form a low-carbon economy and an energy-conservation mentality. In times of global economic growth, Korean logistics enterprises chose cold chain logistics with higher added value to enter overseas markets, and pointed out that the development of an emerging logistics market cannot do without the cooperation between central and local governments and private enterprises, as well active strategies to encourage investment $[23,24]$. In addition, social, environmental, and technological factors also influence the sustainable development of cold chain logistics $[6,21]$.

However, those studies seldom explore the influencing factors that indicate the development level of cold chain logistics, which are important in policymaking and innovating operation modes. In addition, the role of the economy in promoting cold chain logistics development is not fully considered.

Meanwhile, the influence of economic development on cold chain logistics has attracted significant scholarly attention. Qin and Tian [25] used the grey clustering method to analyze the development level of cold chain logistics in regions with significant agricultural production in China. The results revealed that regional differences in economic development and resource distribution affect the regional development level of Chinese agricultural cold chain logistics. The higher the pace of economic progress and the richer the resources, the higher the level of regional agricultural cold chain logistics development. Park [26] investigated the influencing factors that determine the location of global cold chain logistics hubs by employing the analytic hierarchy process (AHP) method, which revealed that the market appeal of the sector was the primary factor. Ikegawa and Tokunaga [27] studied the factors influencing the location of Japanese frozen food companies in foreign countries. They found that the geographical factors that determine a company's decision to enter foreign markets are affected by the popularity of refrigerators and by well-known cost reduction factors, such as wage levels, levels of national investment, and support from government policies. Zhang and Pang [28] estimated that the cold chain logistics joint distribution technology in developed countries is generally mature, and the level of urban economic development affects the development of urban fresh 
agricultural products cold chain logistics. That is, the more prosperous the urban economy, the swifter the development of urban fresh agricultural products cold chain logistics, and their research mainly focuses on the cold chain logistics for agricultural products. Also, economic growth has boosted the consumers' disposable income and improved living standards. Consequently, consumers attached great importance to timely delivery, safety and quality of fresh agricultural products, and scholars are exploring ways to create and optimize cold chain logistics processes in terms of vehicles [6, 29], inventory strategy [30,31] and information transmission $[32,33]$, In turn, all these contribute to the development of cold chain logistics.

Despite the extensive scholarly attention and thorough research on the topic, existing literature neglects several important aspects, which can enhance our understanding of the close relationship between cold chain logistics and the economy. First, in the empirical analyses of the relationship between cold chain logistics and economic development, existing research lacks a comprehensive evaluation of the development level of cold chain logistics. Current research only aims at probing the service level or benefits level of cold chain logistics and, to the best of our knowledge, not a single study attempts to appreciate the overall level of development of cold chain logistics. Second, only a few scholars have investigated the development of cold chain logistics and the economy in China, and none has approached it from a macro perspective. Third, scholars have concentrated their attention on the impact of cold chain logistics on the economy and fail to fully appreciate the correlation between economic factors and cold chain logistics, such as GDP per capita, per capita disposable income gap, and household consumption level. Instead, scholars dwell more on the indirect impact of economic development on cold chain logistics. Therefore, it is necessary to construct a reliable and applicable evaluation system to measure the coupling coordinated relationship of cold chain logistics and economic development, to analyze the main factors affecting their coordinated development, to provide useful insights, and to suggest future directions for the development of the industry and the economy.

\section{Data sources and methodology}

\subsection{Data sources}

The data used to evaluate the relationship between the coordinated development of the Chinese cold chain logistics industry and the overall economy were derived from the China Statistical Yearbook (2010-2020), the Statistical Bulletin of National Economic and Social Development, the China Cold Chain Development Report (2010-2020), the China Cold Chain Logistics Industry Market Prospect and Investment Strategy Analysis Report (2017-2020), and the China Logistics Statistics Yearbook (2010-2020).

\subsection{Construction of the evaluation index system}

The comprehensive evaluation method is generally applicable to evaluate the coordinated development of different systems [34]. Coupled with the findings of other researchers, this paper established an index evaluation system including economic development and cold chain logistics. The comprehensive economic development evaluation index system included 3 evaluation dimensions and 10 evaluation indicators, and the comprehensive cold chain logistics evaluation index system included 3 evaluation dimensions and 10 evaluation indicators, as shown in Table 1.

For the purpose of this paper, we measured the comprehensive evaluation index system of economic development with the use of the following different dimensions:

1. Economic growth level

Economic growth level refers to the increase of economic efficiency and the optimization of 
Table 1. Evaluation index system for cold chain logistics and economic development.

\begin{tabular}{|c|c|c|c|}
\hline System & Dimension & Indicator & Code \\
\hline \multirow{10}{*}{$\begin{array}{l}\text { Economic } \\
\text { development }\end{array}$} & \multirow[t]{4}{*}{ Economic growth level } & The per capita GDP (Yuan) & Y1 \\
\hline & & Total investment in fixed assets (billion Yuan) & $\mathrm{Y} 2$ \\
\hline & & The added value in the tertiary industry (billion Yuan) & Y3 \\
\hline & & The per capita retail sales of consumer goods (Yuan) & $\mathrm{Y} 4$ \\
\hline & \multirow[t]{2}{*}{ Foreign trade level } & The ratio of total import and export trade to GDP (\%) & Y5 \\
\hline & & The ratio of direct foreign investment to GDP (\%) & Y6 \\
\hline & \multirow[t]{4}{*}{ Living standards } & The per capita main food consumption $(\mathrm{Kg})$ & Y7 \\
\hline & & The per capita disposable income gap (Yuan) & Y8 \\
\hline & & The number of Employees (ten thousand) & Y9 \\
\hline & & Household consumption levels (Yuan) & Y10 \\
\hline \multirow[t]{10}{*}{ Cold chain logistics } & \multirow[t]{2}{*}{ Cold chain logistics development benefits } & The ratio of cold chain road transportation revenue to total sector revenue (\%) & $\mathrm{X} 1$ \\
\hline & & $\begin{array}{l}\text { The ratio of combined revenues of the top } 100 \text { cold chain enterprises to total } \\
\text { sector revenue (\%) }\end{array}$ & $\mathrm{X} 2$ \\
\hline & \multirow{4}{*}{$\begin{array}{l}\text { Cold chain logistics development and operational } \\
\text { capacity }\end{array}$} & Total value of food transported (billion Yuan) & $\mathrm{X} 3$ \\
\hline & & The growth rate of cold chain freight transported via road networks (\%) & $\mathrm{X} 4$ \\
\hline & & The turnover of road cold chain freight (million tons $/ \mathrm{km}$ ) & $\mathrm{X} 5$ \\
\hline & & Food cold chain logistics demand (ten thousand tons) & $\mathrm{X} 6$ \\
\hline & \multirow[t]{4}{*}{ Cold chain logistics development foundation } & The volume of human-power employed in cold chain logistics (ten thousand) & $\mathrm{X} 7$ \\
\hline & & The growth rate of expenditure of urban cold chain logistics (\%) & $\mathrm{X} 8$ \\
\hline & & The per capita cold storage capacity $\left(\mathrm{m}^{3} /\right.$ person $)$ & $\mathrm{X} 9$ \\
\hline & & The growth rate of the overall number of refrigerated vehicles (\%) & $\mathrm{X} 10$ \\
\hline
\end{tabular}

https://doi.org/10.1371/journal.pone.0264561.t001

economic structure. GDP is one of the most commonly suitable indicators to estimate the level of economic development [10,34-36], yet more indicators can be found in other evaluation systems due to different evaluation purposes. For example, the investment in social fixed assets affects direct foreign investment and the sustainability of economic growth, while the stable progress of the tertiary industry and the increase in per capita retail sales of consumer goods allow the optimization of the economy's structure [37-39]. Thus, we selected four indicators to evaluate the level of economic growth: the per capita GDP, total investment in fixed assets, the value added in the tertiary industry, and the per capita retail sales of consumer goods.

2. Foreign trade level

Foreign trade level plays an important part in driving economic development and can function as an index that captures the degree of economic activity in China. The inflow and outflow of foreign capital can reflect prospects of and potential for economic development [37, $40,41]$. Therefore, we selected two indicators to measure foreign trade level: the ratio of total import and export trade to GDP and the ratio of direct foreign investment to GDP.

3. Living standards

Living standards are another important indicator to measure economic development [42, 43]. The per capita main food consumption, the per capita disposable income gap, and household consumption levels can be used as indicators, the number of employees reflects the activity of the market economy, and the development of the market economy affects people's living standards. Improved values for these indicators suggest narrower social and income inequalities, which can shape a stable environment that facilitates economic growth. Hence, we used these four indicators to assess living standards in China. 
To create the comprehensive evaluation index system of cold chain logistics we used the following different dimensions:

1. Cold chain logistics development benefits

This dimension was measured by two indicators: the ratio of road cold chain transportation revenue to total revenue, and the ratio of the combined revenues of the top 100 cold chain enterprises to total sector revenue. The road transportation revenue is the core component of cold chain logistics revenue. What's more, given that cold chain logistics enterprises are an important element in the cold chain logistics industry, their profitability reflects the benefit for the industry.

2. Cold chain logistics development and operational capacity

The transportation capacity and demand for perishable food or cold chain logistics services reflect the development and operational capacity of the sector. Because the larger part of turnover originates in the distribution of fresh agricultural products, the number of operators and total freight volume rise together with the increasing consumer demand for fresh agricultural products. The higher the turnover of goods, the faster the distribution speed, the steeper the growth of freight volume, and the stronger the transportation capacity of cold chain logistics. According to a report from the China Cold-chain Logistics Association [5], the availability of other modes of transportation notwithstanding, road transportation comprised $80 \%$ of the total transportation volume of refrigerated and frozen foods. For this reason, four indicators were used to determine the development and operation capacity of cold chain logistics: total value of food transported the growth rate of cold chain freight transported via road networks, the turnover of road cold chain freight, and food cold chain logistics demand.

3. Cold chain logistics development foundations

The foundations for the development of cold chain logistics refer to the factors that support the development of cold chain logistics activities. Cold chain products are common in urban distribution, and distribution providers take into consideration the perishability and short storage time of cold chain products, they have high requirements for time and infrastructure in the transportation process. Hence, substantial investment in infrastructure is a prerequisite for optimizing cold chain transportation, such as reasonable increases of the required cold storage capacity and the quantity of refrigerator trucks [1, 44-47]. At the same time, the increasing demand for refrigerated and frozen foods has led to the growth of home delivery cold chain services [48]. In view of the fact that agricultural products must be stored at low temperature during transportation and any failure to comply with such requirements will compromise the quality and safety of products [49-52]. Consequently, careful planning of the entire transportation process of products from cold storage to end consumers onboard refrigerated vehicles between cold chain links is of the utmost necessity. Thus, four indicators were used to weigh the cold chain logistics development foundation: the volume of human-power employed in cold chain logistics, the growth rate of expenditure of urban cold chain logistics, the per capita cold storage capacity, and the growth rate of the overall number of refrigerated vehicles.

\subsection{Entropy weighting method (EWM)}

EWM, originally developed by Shannon [53], is used to establish objective weights for attributes or responses. The probability theory is applied to calculate uncertain information (entropy) and determine the importance of each attribute excluding decider preferences [40, 
54, 55]. EWM was applied to determine the indicator weight of economic development systems and cold chain logistics systems. The application of entropy weight can effectively decrease the subjectivity of weight decisions. The specific steps of analysis were as follows:

1. Standardizing each indicator $\left(x_{i j}\right)$ : As the units and magnitudes of the indicators were inconsistent, and each indicator had a positive or negative impact on the system, they could not be compared directly. Standardization of the indicators' benefits eliminated the influence of units, magnitudes, and types on the subsystem [40]. Given an research problem with $m$ research objects and $n$ evaluating indicators, $a_{i j}$ is the value of the $j$ th $(j=1,2,3 \ldots n)$ indicator under the $i$ th $(i=1,2,3 \ldots m)$ object. The original data matrix $a=\left(a_{i j}\right)^{\prime}{ }_{m \times n}$ was constructed. Then, the matrix $a$ was translated to $x_{i j}=\left(a_{i j}\right)_{m \times n}$ with standardization. $x_{i j}\left(0 \leq x_{i j} \leq 1\right)$ denotes the value in the $i$ th object related to $j$ th evaluation indicator, as calculated with the use of Eq (1):

$$
x_{i j}= \begin{cases}\frac{a_{i j}-\min \left(a_{i j}\right)}{\max \left(a_{i j}\right)-\min \left(a_{i j}\right)} ; & a_{i j}: \text { positive index } \\ \frac{\max \left(a_{i j}\right)-a_{i j}}{\max \left(a_{i j}\right)-\min \left(a_{i j}\right)} ; & a_{i j}: \text { negative index }\end{cases}
$$

2. Calculating the information entropy $\left(e_{j}\right)$ as in Eq (2):

$$
e_{j}=-(\operatorname{Inm})^{-1} \sum_{i=1}^{i=m} p_{i j} \operatorname{In} p_{i j}
$$

Where $p_{i j}=\frac{x_{i j}}{\sum_{i=1}^{i=m} x_{i j}}$ represents the ratio of the $i$ th evaluation object $x_{i j}$ under the $j$ th indicator. If $p_{i j}=0$, then $p_{i j} \operatorname{In} p_{i j}=0$.

3. Calculating indicator weights $\left(w_{j}\right)$ as in $\mathrm{Eq}(3)$ :

$$
w_{j}=\frac{1-e_{j}}{\sum\left(1-e_{j}\right)}
$$

\subsection{Coupling coordination degree model (CCMD)}

The CCMD, which entails the concept of sustainable development, is significant for measuring the coordination of logistics and economic development [56]. Coupling degree is a concept introduced from and widely used in physics, but it features in other research fields too because of the similar coupling relationship between systems [57]. When subsystems within a system reach the state of coupling and coordinated development, their positive influence is significant, which is beneficial to the sustainable development of the system $[58,59]$. The CCMD in physics was utilized to estimate the coupling relationship. The aim was to reflect the development level and coordination effect of cold chain logistics and the economy as a whole, and effectively measure the level of coordinated development between the two, given as follows:

1. Developing the coupling degree (C). The coupling degree indicates the extent to which the cold chain logistics system and the economic development system correlate through their respective coupling factors. Depending on the scale of the coupling degree, cold chain logistics and economic development are classified into four coupling stages, as 
Table 2. Coupling stages and judgment criteria.

\begin{tabular}{l|c|c|c|c}
\hline Coupling effect & Low level coupling stage & Antagonistic stage & Fitting in stage & High level coupling stage \\
\hline Coupling degree $C$ & {$[0,0.3]$} & {$[0.3,0.5]$} & {$[0.5,0.8]$} & {$[0.8,1]$}
\end{tabular}

shown in Table 2. The values of $\mathrm{C}$ are expressed in Equation:

$$
C=\frac{2 \sqrt{U G}}{U+G}
$$

Where $U=\sum_{i=1}^{i=n} w_{j} x_{j}$ is the comprehensive development index for cold chain logistics and $G=\sum_{j=1}^{j=n} w_{j} x_{j}$ is the comprehensive development index for the economy. The comprehensive development index reflects the comprehensive development level of each system.

2. Estimating the coupling coordination degree (D). The coupling coordination degree measures the extent of the interdependence, coordination, and mutual promotion between cold chain logistics and the economy; the stronger the relationship, the higher the index. The values of $\mathrm{D}$ are calculated with the use of $\mathrm{Eq}(5)$ :

$$
D=\sqrt{C T}
$$

Where $T=\alpha U_{i}+\beta G_{i}$ is the comprehensive evaluation index between cold chain logistics and the economy, and $\alpha$ and $\beta$ are the weight coefficients of each system. It is assumed that cold chain logistics and the economy are equally important, hence $\alpha=\beta=0.5[34,59,60]$. Therefore: $\mathrm{C} \in[0,1] . \mathrm{D} \in[0,1]$, and the higher the value of $\mathrm{D}$, the higher the coupling coordination degree. According to $[34,58,61]$, types of coupling coordination degrees in the study were divided into ten levels, as shown in Table 3.

\subsection{Grey relational analysis (GRA)}

GRA, originally proposed by Deng [62], entails the quantitative description and comparison of the developmental change of the dynamics in a system and is a useful tool to construct a prediction model that explains the response dependence on input parameters [20, 63-65]. In view of the correlation and time sequence between cold chain logistics and the economy, GRA was performed to analyze the main factors influencing the coordinated development of cold chain logistics and the economy as follows:

1. Computing the correlation coefficient $\left(\gamma_{i j}\right) . Z_{i}(k)$ and $Q_{j}(k)$ represent the standardized values of cold chain logistics and economic indicators respectively. $\rho$ is the distinguishing

Table 3. Coupling coordination grade and criterion.

\begin{tabular}{l|l|l|l}
\hline Coordination grade & Coordination degree & Coordination grade & Coordination degree \\
\hline Extreme imbalance & {$[0,0.1]$} & Coordination & {$[0.5,0.6]$} \\
\hline Serious imbalance & {$[0.1,0.2]$} & Basic coordination & {$[0.6,0.7]$} \\
\hline Moderate imbalance & {$[0.2,0.3]$} & Moderate coordination & {$[0.7,0.8]$} \\
\hline Mild imbalance & {$[0.3,0.4]$} & Good coordination & {$[0.8,0.9]$} \\
\hline Imbalance & {$[0.4,0.5]$} & High quality coordination & {$[0.9,1]$} \\
\hline
\end{tabular}

https://doi.org/10.1371/journal.pone.0264561.t003 
Table 4. Coupling strength and discrimination criteria.

\begin{tabular}{l|l|l|l|l}
\hline Coupling effect & Weak & Moderate & Strong & Extremely strong \\
\hline Correlation degree $\varphi_{i j}$ & {$[0,0.35]$} & {$[0.35,0.65]$} & {$[0.65,0.85]$} & {$[0.85,0.1]$}
\end{tabular}

https://doi.org/10.1371/journal.pone.0264561.t004

coefficient and generally takes the value of 0.5 (usually $\rho \in[0,1]$ ) [65]. The values of $\gamma_{i j}$ are calculated by $\mathrm{Eq}(6)$ as follows:

$$
\gamma_{i j}\left(Z_{\mathrm{i}}(\mathrm{k}), \mathrm{Q}_{\mathrm{j}}(\mathrm{k})\right)=\frac{\min \min \left|Z_{i}(k)-Q_{j}(k)\right|+\rho \max \max \left|Z_{i}(k)-Q_{j}(k)\right|}{\left|Z_{i}(k)-Q_{j}(k)\right|+\rho \max \max \left|Z_{i}(k)-Q_{j}(k)\right|}
$$

2. Obtaining the grey relational matrix $\left(\varphi_{i j}\right)$. The correlation coefficient $\gamma_{i j}$ is averaged according to sample size. The closeness of the relationship between the evaluation indicators of the two systems can be analyzed by comparing the values of $\varphi_{i j}$. The higher the $\varphi_{i j}$, the stronger the correlation between the two indicators and the stronger the coupling; reversely, the lower the $\varphi_{i j}$, the weaker the correlation and the coupling. The intensity of the coupling effect are scaled into four stages, as shown in Table 4 . The values of $\varphi_{i j}$ are represented as Eq (7):

$$
\varphi_{i j}=\frac{1}{n} \sum_{k=1}^{n} \gamma_{i j}\left(Z_{i}(k), Q_{j}(k)\right)
$$

\section{Results and analysis}

\subsection{EWM to calculate weight}

The EWM was applied to calculate the weight of indicators reflecting the development level of cold chain logistics and economic development level. The results could be obtained via Eqs (1), (2), and (3), as shown in Table 5.

Table 5 shows that 'the ratio of total import and export trade to GDP' indicator was the most significant factor affecting the development of the economy with a percentage weight of $14.58 \%$, followed by 'the ratio of foreign direct investment to GDP' (14.13\%) and 'the added value in the tertiary industry' (10.49\%) indicators. The main indicator 'food cold chain logistics demand' was the most significant factor affecting the development level of cold chain logistics with a percentage weight of $14.86 \%$, followed by 'the growth rate of cold chain freight transported via road networks' (14.03\%) and 'the ratio of combined revenues of the top 100 cold chain enterprises to total sector revenue' (13.53\%).

\subsection{Coupling relationship comprehensive assessment}

The CCMD based on EWM was employed to analyze the coupling coordination of cold chain logistics and economic development. After solving Eqs (4) and (5), the results of coupling degree, coupling coordination degree, and their respective comprehensive development indicator of the two systems were obtained. Combined with Tables 2 and 3, the coupling stage and coupling coordination degree of the two was determined, as shown in Table 6 and Fig 1.

Table 6 and Fig 1 show that from 2010 to 2019 the coupling coordination degree and the comprehensive development indexes between cold chain logistics and the economy had all increased at different paces. The cold chain logistics comprehensive development index fluctuated more widely compared with the economic comprehensive development index. Moreover, 
Table 5. Index weight for cold chain logistics and economy.

\begin{tabular}{|c|c|c|c|}
\hline System & Dimension & Indicator & $\begin{array}{l}\text { Weight } \\
(\%)\end{array}$ \\
\hline \multirow{10}{*}{$\begin{array}{l}\text { Economic } \\
\text { development }\end{array}$} & \multirow[t]{4}{*}{ Economic growth level } & The per capita GDP (Yuan) & 9.15 \\
\hline & & Total investment in fixed assets (billion Yuan) & 8.17 \\
\hline & & The added value in the tertiary industry (billion Yuan) & 10.49 \\
\hline & & The per capita retail sales of consumer goods (Yuan) & 9.42 \\
\hline & \multirow[t]{2}{*}{ Foreign trade level } & The ratio of total import and export trade to GDP (\%) & 14.58 \\
\hline & & The ratio of direct foreign investment to GDP (\%) & 14.13 \\
\hline & \multirow[t]{4}{*}{ Living standards } & The per capita main food consumption $(\mathrm{Kg})$ & 8.84 \\
\hline & & The per capita disposable income gap (Yuan) & 8.49 \\
\hline & & The number of Employees (ten thousand) & 7.01 \\
\hline & & Household consumption levels (Yuan) & 9.72 \\
\hline \multirow[t]{10}{*}{ Cold chain logistics } & \multirow[t]{2}{*}{ Cold chain logistics development benefits } & The ratio of cold chain road transportation revenue to total sector revenue (\%) & 4.07 \\
\hline & & $\begin{array}{l}\text { The ratio of combined revenues of the top } 100 \text { cold chain enterprises to total } \\
\text { sector revenue (\%) }\end{array}$ & 13.53 \\
\hline & \multirow{4}{*}{$\begin{array}{l}\text { Cold chain logistics development and } \\
\text { operational capacity }\end{array}$} & Total value of food transported (billion Yuan) & 10.60 \\
\hline & & The growth rate of cold chain freight transported via road networks (\%) & 14.03 \\
\hline & & The turnover of road cold chain freight (million tons $/ \mathrm{km}$ ) & 9.49 \\
\hline & & Food cold chain logistics demand (ten thousand tons) & 14.86 \\
\hline & \multirow[t]{4}{*}{ Cold chain logistics development foundation } & The volume of human-power employed in cold chain logistics (ten thousand) & 9.97 \\
\hline & & The growth rate of expenditure of urban cold chain logistics (\%) & 8.34 \\
\hline & & The per capita cold storage capacity ( $\mathrm{m}^{3} /$ person) & 7.37 \\
\hline & & The growth rate of the overall number of refrigerated vehicles (\%) & 7.76 \\
\hline
\end{tabular}

the former was significantly lower than the latter before 2018, which indicates that the development rate of cold chain logistics was lower. After 2018, cold chain logistics developed rapidly and exceeded the rates of economic development. Additionally, the coupling degree (between

Table 6. Evaluation results for coupling relationship between cold chain logistics and economy.

\begin{tabular}{|c|c|c|c|c|c|c|}
\hline Year & $\begin{array}{l}\text { Cold chain logistics comprehensive } \\
\text { development index } U\end{array}$ & $\begin{array}{l}\text { Economic comprehensive } \\
\text { development index } G\end{array}$ & $\begin{array}{l}\text { Coupling } \\
\text { degree } C\end{array}$ & Coupling stages & $\begin{array}{l}\text { Coupling coordination } \\
\text { degree } D\end{array}$ & $\begin{array}{l}\text { Coupling } \\
\text { coordination grade }\end{array}$ \\
\hline 2010 & 0.2033 & 0.3904 & 0.9490 & $\begin{array}{l}\text { High level } \\
\text { coupling stage }\end{array}$ & 0.5307 & Coordination \\
\hline 2011 & 0.2881 & 0.3964 & 0.9874 & $\begin{array}{c}\text { High level } \\
\text { coupling stage }\end{array}$ & 0.5813 & Coordination \\
\hline 2012 & 0.2405 & 0.3708 & 0.9770 & $\begin{array}{c}\text { High level } \\
\text { coupling stage }\end{array}$ & 0.5465 & Coordination \\
\hline 2013 & 0.3642 & 0.4744 & 0.9913 & $\begin{array}{c}\text { High level } \\
\text { coupling stage }\end{array}$ & 0.6447 & Basic coordination \\
\hline 2014 & 0.4205 & 0.4840 & 0.9975 & $\begin{array}{l}\text { High level } \\
\text { coupling stage }\end{array}$ & 0.6717 & Basic coordination \\
\hline 2015 & 0.4011 & 0.4834 & 0.9957 & $\begin{array}{l}\text { High level } \\
\text { coupling stage }\end{array}$ & 0.6636 & Basic coordination \\
\hline 2016 & 0.3481 & 0.5304 & 0.9782 & $\begin{array}{c}\text { High level } \\
\text { coupling stage }\end{array}$ & 0.6555 & Basic coordination \\
\hline 2017 & 0.3969 & 0.5582 & 0.9856 & $\begin{array}{c}\text { High level } \\
\text { coupling stage }\end{array}$ & 0.6861 & Basic coordination \\
\hline 2018 & 0.5075 & 0.5689 & 0.9984 & $\begin{array}{l}\text { High level } \\
\text { coupling stage }\end{array}$ & 0.7330 & $\begin{array}{l}\text { Moderate } \\
\text { coordination }\end{array}$ \\
\hline 2019 & 0.7186 & 0.5954 & 0.9956 & $\begin{array}{l}\text { High level } \\
\text { coupling stage }\end{array}$ & 0.8088 & Good coordination \\
\hline
\end{tabular}




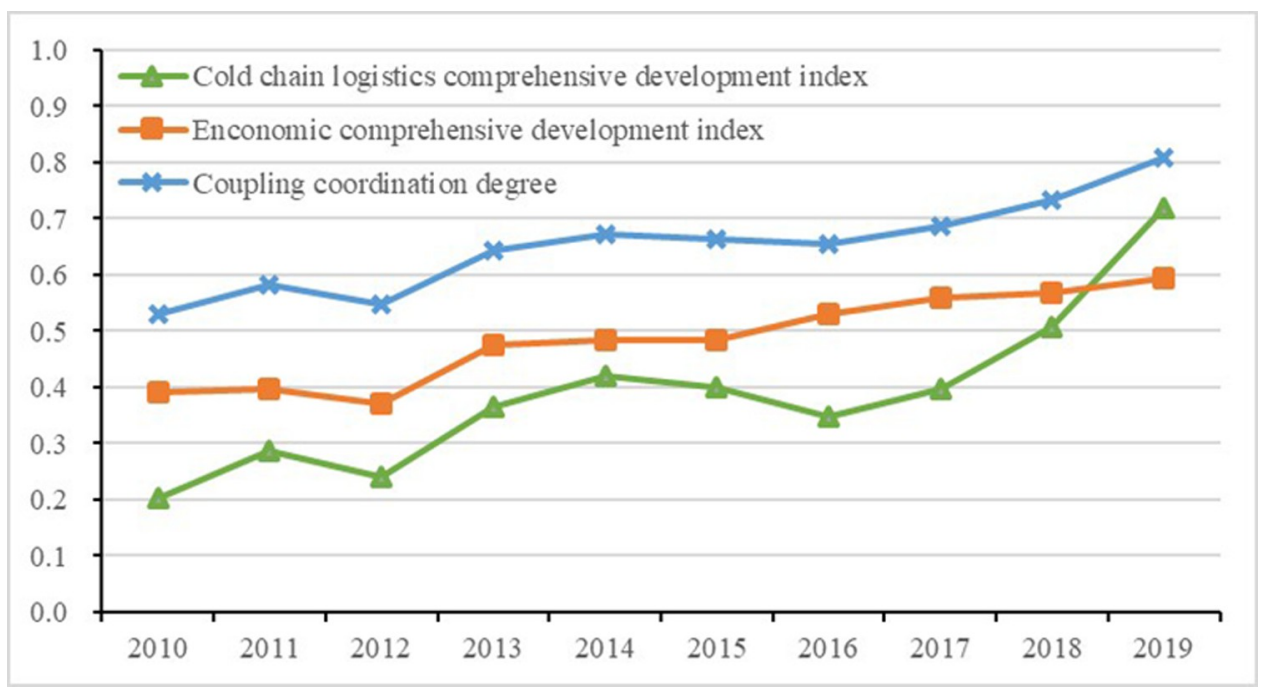

Fig 1. Trend in coupling relationship from 2010 to 2019.

https://doi.org/10.1371/journal.pone.0264561.g001

0.9490 and 0.9956 ) was obviously higher than the coupling coordination degree (between 0.5307 and 0.8088 ), mainly because the coupling degree only measures consistency and synchronization. The lower the comprehensive development index of cold chain logistics and the economy, the higher the coupling degree [60]. Therefore, the coupling coordination degree can reflect accurately the coordinated development level of the system.

Overall, the coupling coordination degree of cold chain logistics and the economy has retained a relatively stable upward trend, as shown in Fig 1 . The development of the two systems has progressed from the 'coordination' to 'good coordination' stage, as shown in Table 6. From 2010 to 2012, the coupling coordination degree fluctuated between 0.5307 and 0.5465 , which shows that the development of cold chain logistics and the economy was at the 'coordination' phase. From 2013 to 2017, the coupling coordination degree fluctuated between 0.6447 and 0.6861 , which suggests that the development of cold chain logistics and the economy were in the transitional phase from 'basic coordination' to 'moderate coordination'. From 2018 to 2019 , the coupling coordination degree fluctuated between 0.7330 and 0.8088 , which shows that the development of cold chain logistics and the economy was in the transitional stage from 'moderate' to 'good coordination'. According to the development stage changes of cold chain logistics and economic development, this study further analyzed the logic of their evolution.

From 2010 to 2012, the implementation of the Logistics Industry Adjustment and Revitalization Plan succeeded in making the logistics industry a sector of strategic importance and created new opportunities for the development of the cold chain logistics industry. A few new enterprises emerged, but the overall level of the industry was far from adequate and the market paid little attention to cold chain logistics.

From 2013 to 2017, as the accelerated process of urbanization increased household consumption and created an unprecedented awareness and pursuit of a healthier lifestyle, fresh foods gradually grew in popularity. National policies and industry standards were further refined. For example, the Ministry of Finance Ministry of Commerce Notice on Central Financial Support for the Development of Cold Chain Logistics, released in 2016, and the Implementation Opinions on Accelerating the Development of Cold Chain Logistics to Safeguard Food Safety and Promote Consumption Upgrading, one year after, aimed to support the development of 
cold chain logistics. They stressed the urgency of increasing financial support for cold chain logistics, upgrading quality monitoring standards for perishable foods (e.g., aquatic products, meat, dairy products, and frozen foods) and completing cold chain logistics infrastructure. Then, government funds were invested in cold chain logistics enterprises, domestic and foreign cold chain companies entered the fresh food market and founded suitable distribution centers (e.g., Sinotrans, Pfizer, Swire, Metro, Walmart). Meanwhile, Chinese fresh e-commerce transactions maintained a high annual growth level of more than $30 \%$. As the primary system of distribution of fresh products, the market has also attached great importance to cold chain logistics. The development of the market economy has further enhanced the coordinated development of cold chain logistics and the economy, although the development of cold chain logistics remained slower than the development of the economy.

From 2018 to 2019, with the improvement of cold chain infrastructure and the continuous optimization of logistics and transportation modes, there developed a growing trend to utilize multimodal transportation in cold chain fresh agricultural products distribution. Moreover, new technologies (e.g., Internet of Things, artificial intelligence, blockchain) became a vigorous driving force for the industry. Over time, cold chain logistics has entered a period of rapid development, to the effect that the comprehensive development rate of cold chain logistics is now higher than the comprehensive growth rate speed of the economy; the two have progressed first to 'moderate' and then to 'good coordination' level.

\subsection{Analysis of main factors affecting the coupling coordination development}

Based on Eqs (6) and (7), we calculated the grey relational matrix reflecting the coupling effect between cold chain logistics and the economy respectively. Combined with Table 4, the coupling strength was determined, as shown in Table 7.

4.3.1. Analysis of economic factors affecting cold chain logistics. Table 7 shows that the most important among the economic factors affecting cold chain logistics was 'the added value in the tertiary industry' with a maximum average correlation degree of 0.7433 , followed by 'the per capita GDP' (0.7322), and 'household consumption levels' (0.7314). Their average correlations all rose to 0.65 , the coupling effect was strong, the average correlation of 'ratio of total import and export trade to GDP' was the lowest one (with an average correlation of 0.584), and the coupling effect with cold chain logistics reached the 'moderate' stage.

In 2019, the added value in the logistics industry accounted for $28.08 \%$ of the total added value across the tertiary industry. As a substantial part of the logistics industry, the total

Table 7. Matrix for the coupling effect of cold chain logistics and economy.

\begin{tabular}{|c|c|c|c|c|c|c|c|c|c|c|c|}
\hline & $\mathrm{X} 1$ & $\mathrm{X} 2$ & $\mathbf{X} 3$ & $\mathrm{X} 4$ & X5 & X6 & X7 & X8 & X9 & X10 & Avg \\
\hline Y1 & 0.6743 & 0.7236 & 0.8299 & 0.4868 & 0.8961 & 0.7735 & 0.8847 & 0.5657 & 0.9400 & 0.5479 & 0.7322 \\
\hline $\mathrm{Y} 2$ & 0.7968 & 0.6165 & 0.6863 & 0.5342 & 0.7268 & 0.6491 & 0.7219 & 0.5197 & 0.7881 & 0.5347 & 0.6574 \\
\hline Y3 & 0.6554 & 0.7511 & 0.8614 & 0.4765 & 0.9326 & 0.7998 & 0.9162 & 0.5516 & 0.9496 & 0.5392 & 0.7433 \\
\hline Y4 & 0.7136 & 0.7020 & 0.7869 & 0.4937 & 0.8387 & 0.7390 & 0.8461 & 0.5312 & 0.9234 & 0.5270 & 0.7102 \\
\hline Y5 & 0.4733 & 0.5976 & 0.4895 & 0.8043 & 0.4743 & 0.5015 & 0.4680 & 0.7903 & 0.4799 & 0.7054 & 0.5784 \\
\hline Y6 & 0.4637 & 0.6575 & 0.5870 & 0.6930 & 0.5585 & 0.5880 & 0.5346 & 0.7851 & 0.5343 & 0.7252 & 0.6127 \\
\hline Y7 & 0.7174 & 0.6310 & 0.7301 & 0.5640 & 0.7484 & 0.7157 & 0.7944 & 0.5113 & 0.776 & 0.5786 & 0.6767 \\
\hline Y8 & 0.5188 & 0.5497 & 0.5275 & 0.7721 & 0.5198 & 0.5166 & 0.5260 & 0.7780 & 0.5362 & 0.6627 & 0.5907 \\
\hline Y9 & 0.8078 & 0.5860 & 0.6444 & 0.5351 & 0.6757 & 0.6156 & 0.6690 & 0.5099 & 0.7209 & 0.5563 & 0.6321 \\
\hline Y10 & 0.6815 & 0.7269 & 0.8254 & 0.4812 & 0.8880 & 0.7697 & 0.8938 & 0.5538 & 0.9570 & 0.5368 & 0.7314 \\
\hline Avg & 0.6503 & 0.6542 & 0.6968 & 0.5841 & 0.7259 & 0.6669 & 0.7255 & 0.6097 & 0.7605 & 0.5914 & 0.6665 \\
\hline
\end{tabular}

https://doi.org/10.1371/journal.pone.0264561.t007 
revenue in cold chain road transportation accounted for $2.42 \%$ of the total revenue in the logistics industry. Hence, the growth of the tertiary industry can quickly boost the development of the logistics industry [36] and capital investment in cold chain logistics [1], while overall economic development can fuel the demand for cold chain logistics services [15, 66]. Moreover, household consumption levels reflect the strength of consumer purchasing power, and consumer spending on cold chain products affects the development of transportation and distribution businesses operating in the cold chain logistics industry.

4.3.2. Analysis of cold chain logistics factors affecting economic development. Table 7 shows that 'the per capita cold storage capacity' had the strongest impact on economic development with an average correlation degree of 0.7605 , followed by 'the turnover of road cold chain freight' (0.7259), and 'the volume of human-power employed in cold chain logistics' (0.7255). The average correlation degree of the indicators rose above 0.65 and the coupling effect was strong, which shows that these three factors were the main ones affecting Chinese economic development. The impact of the growth rate of cold chain freight transported via road networks was the least important one, but the correlation degree was still 0.578 and the coupling effect was at the 'moderate' stage.

Investment in transportation and logistics infrastructure restricts the development of the logistics industry and direct foreign investment, which in turn affects sustainable economic growth $[10,37,56]$. Based on the uncertain consumer demand, cold storage capacity has an adjustment effect on the uneven distribution of cold chain products in time and space in the process of cold chain logistics development. However, Chinese actual per capita cold storage capacity is less than half of that of more developed countries in Europe and America, and of Japan. Thereby, the scale of cold storage capacity limits the development level of the cold chain logistics market as well as the development of the regional economy.

Regarding the impact of road cold chain freight turnover on the economy, the relationship between the development of China's freight volume and GDP has become increasingly closer. Since the beginning of the $20^{\text {th }}$ century, the correlation between freight turnover and GDP has increased slightly [67]. In conditions of increasingly fierce competition in the transportation market, the ratio of road cold chain transportation to sea transportation, railway transportation and air transportation rose to $88.97 \%$ in 2019 , according to the China Cold-chain Logistics Association [5]. The turnover of highway cold chain freight seems to indicate that consumer demand and the demand for fresh and frozen products affect the development of the market economy. However, the impact of scattered consumers distribution, diverse demand, and inadequate transportation makes it impossible for operators to deliver small volumes and multiple batches of goods directly, resulting in an increase in the turnover of cold chain transportation and distribution costs. Furthermore, the contribution of the industry to economic development is finally weakened.

With respect to the impact of the number of cold chain logistics employees on the economy, the traditional cold chain logistics process relies more on labor force, and investment in labor force determines operational efficiency and economic benefits. With the advent of modern information and artificial intelligence, the efficiency of cold chain logistics activities was improved with the help of the Internet of things, big data, and digital empowerment precipitated immense changes in the economy $[6,68]$.

\section{Policy recommendations}

The relationship between Chinese cold chain logistics and economic development is a key topic of research and future government policies can draw on our findings to better tailor their intervention to meet market needs. Moreover, because China is a developing country, the 
study of the coordinated development of cold chain logistics and the economy can inform decisions in other developing countries too. As the overall economy will continue to grow, the coordination and interaction between cold chain logistics and economic development appear almost inevitable. To promote the sustainable and coordinated development of Chinese cold chain logistics and the economy, we express the following recommendations:

1. Transform the cold chain logistics pattern. The increase in private disposable income and higher consumption levels have boosted total retail sales of consumer goods. Furthermore, consumption patterns of frozen and fresh foods have changed and adaptation to new market conditions is a necessity for cold chain logistics. Enterprises operating in the market should standardize fresh food distribution and set up a cold chain network to provide comprehensive, effective, timely, and regular services. In addition, the creation of a smart monitoring platform to oversee the entire process should not only allow efficient monitoring of online orders, but also make temperature and humidity levels visible and controllable. For example, across the Chinese cold chain logistics market, which was severely impacted by the COVID-19 pandemic in 2020, there emerged new models, new business types and new technologies (e.g., "fresh food e-commerce + cold chain delivery", "central kitchen + food materials cold chain distribution") for handling and transporting fresh agricultural products, which ensured the timely delivery of fresh and frozen products to the customer's door, and centralized processing of those products created more opportunities to stimulate consumption, accelerate the development of the industry, but also had a cumulating effect in driving the development of the online and digital economy.

2. Improve the cold chain logistics infrastructure. Favorable infrastructure is conducive to the successful operation of the entire network. The completion of the transportation network promotes economic development by reducing delivery time, decreasing cargo damage costs, and improving customer satisfaction. Reversely, overall economic development provides incentives to invest in transportation infrastructure. Strategies and plans to improve the infrastructure may include the following: improvement of the road transportation network; coordination and integration of the railway, sea, and air transportation networks to facilitate multimodal transport; increase cold storage capacity; upgrade refrigerated vehicles; development of a comprehensive information service system as soon as possible; optimization of the cold chain product information traceability system; integration of smart technologies to effectively plan cold chain transportation routes and select cold storage layout points.

3. Standardize the cold chain logistics guidelines. In all stages of the process (harvesting, precooling, transportation, and distribution from the place of origin to the customer's door), the control of humidity, temperature, and delivery time strongly affects product quality and safety. To meet the primary consumer demand for freshness and safety, effective management should be established to manage handover, transportation, distribution, storage, personnel, delivery tracking, product recall policy and process, documentation, and other aspects.

4. Train cold chain logistics experts. The industry relies on interdisciplinary specialist knowledge and demands a holistic approach that combines theory and practice. Hence, it is important for the sustainability and efficiency of the industry to recruit and train skillful employees who understand theory and refined technology. For example, technical and operational managers must have a working knowledge of chemistry and specific chemicals involved, such as ammonia, Freon, and Teflon, and be familiar with the operation of cold storage. 


\section{Conclusions}

Based on the panel data relating to Chinese cold chain logistics and the overall economic development from 2010 to 2019, this paper examined the coupling relationship between Chinese cold chain logistics and the economy, and analyzed the main factors affecting their coordinated development. The research findings can be described as follows:

1. From 2010 to 2019, the coupling coordination degree of Chinese cold chain logistics and economic development fluctuated between 0.5307 and 0.8088 , which indicates progress from 'coordination' to 'good coordination' level. Additionally, the coupling coordination degree showed a stable upward trend. In general, the synergy effect between cold chain logistics and economic development could do with improvement.

2. The coupling relationship between cold chain logistics and economic development has become increasingly close. Their coordinated development was mostly supported by the development of the economy until 2018, before cold chain logistics entered a phase of rapid development that ushered in a sustainable, coordinated development.

3. Among the evaluation indicators for economic development, 'the added value in the tertiary industry', 'the per capita GDP', and 'household consumption levels' were the main ones affecting the development of cold chain logistics (the former returning the highest average correlation degree and exerting the greatest influence).

4. Among evaluation indicators for cold chain logistics, 'the per capita cold storage capacity', 'the turnover of road cold chain freight', and 'the volume of human-power employed in cold chain logistics' were the main ones affecting economic development (the former displaying the highest average correlation degree and exerting the greatest impact).

5. There is still a long way to go before achieving satisfactory levels of coordinated, sustainable development between cold chain logistics and the economy. In light of the current situation in the industry and the main factors influencing the coordinated development of cold chain logistics and the economy, we proposed specific strategies to attain the coordinated development of the two.

The main contributions of this study are as follows:

1. The construction of an evaluation indicators system suitable to objectively and comprehensively assess cold chain logistics and economic development, which can better analyze and study the coupling relationship of the two.

2. This study adopted the EWM and CCDM to measure the development status and coupling coordination level of cold chain logistics and economic development. Both EWM and CCDM proved valid methods to measure the coordinated development of the two. Moreover, this paper fills the gap in the literature on the coupling relationship between cold chain logistics and economic development.

3. The paper articulates concrete and feasible recommendations appropriate for the development of cold chain logistics and economic development. These recommendations assist in better understanding the coupling coordination relationship between the two in terms of evaluation content, and support the optimization of the evaluation system and its application in assessing their coordinated development. 


\section{Limitations and future research directions}

Chinese cold chain logistics are late-comers in an industry that benefits from longevity elsewhere (Japan, the United States, Germany, and other developed countries). With a weaker foundation and an unsatisfactory system, the industry lacks comprehensive statistical data (such as decay rates of fresh products or circulation rates of fresh agricultural products) to measure its own development, Therefore, No evaluation system of cold chain logistics can be flawless or beyond criticism. Future research can collect relevant cold chain measurement indicators more thoroughly, and expand the scope by studying the relationship between cold chain logistics and other industries, such as the financial industry or e-commerce. Lastly, national policies and economic input are often not in sync with the development of cold chain logistics. Sometimes, substantial capital investment in the industry requires time to affect the development of cold chain logistics. The temporal gap necessary to catch up with financial input for government spending to yield results invites further research.

\section{Supporting information}

S1 Raw data.

(XLSX)

S1 File.

(DOCX)

\section{Acknowledgments}

The authors are very grateful to anonymous reviewers for their attention to this study and useful comments.

\section{Author Contributions}

Data curation: Hong Huang.

Funding acquisition: Ruhe Xie.

Investigation: Hong Huang.

Supervision: Ruhe Xie, Yuan Zhang, Peiyun Yu.

Writing - original draft: Hong Huang.

Writing - review \& editing: Hong Huang.

\section{References}

1. Zhao H, Liu S, Tian C, Yan G, Wang D. An overview of current status of cold chain in China. International Journal of Refrigeration. 2018; 88:483-495. https://doi.org/10.1016/j.ijrefrig.2018.02.024

2. Ning XL. Chinese food cold chain logistics mode. China Logistics \& Purchasing. 2010; 2:68-69.

3. Lan H, Tian Y. Analysis of the demand status and forecast of food cold chain in Beijing. Journal of Industrial Engineering and Management. 2013; 6(1):346-366. https://doi.org/10.3926/jiem.675

4. Zhu X, Zhang R, Chu F, He Z, Li J. A Flexsim-based Optimization for the Operation Process of Cold Chain Logistics Distribution Centre. Journal of Applied Research and Technology. 2014; 12(2):270278. https://doi.org/10.1016/S1665-6423(14)72343-0

5. China cold-chain logistics development report [press release]. Beijing: China Fortune Press 2020.

6. Han J, Zuo M, Zhu W, Zuo J, Lü E, Yang X. A comprehensive review of cold chain logistics for fresh agricultural products: Current status, challenges, and future trends. Trends in Food Science \& Technology. 2021; 109:536-551. https://doi.org/10.1016/j.tifs.2021.01.066 
7. James SJ, James C. The food cold-chain and climate change. Food Research International. 2010; 43:1944-1956. https://doi.org/10.1016/j.foodres.2010.02.001

8. Wu J-Y, Hsiao H-I. Food quality and safety risk diagnosis in the food cold chain through failure mode and effect analysis. Food Control. 2021; 120. https://doi.org/10.1016/j.foodcont.2020.107501

9. Yu Y, Xiao T. Analysis of cold-chain service outsourcing modes in a fresh agri-product supply chain. Transportation Research Part E: Logistics and Transportation Review. 2021; 148:102264. https://doi. org/10.1016/j.tre.2021.102264

10. Lan S, Yang C, Huang GQ. Data analysis for metropolitan economic and logistics development. Advanced Engineering Informatics. 2017; 32:66-76. https://doi.org/10.1016/j.aei.2017.01.003

11. Cang Y-m Wang D-c. A comparative study on the online shopping willingness of fresh agricultural products between experienced consumers and potential consumers. Sustainable Computing: Informatics and Systems. 2021; 30:100493. https://doi.org/10.1016/j.suscom.2020.100493

12. Zhou $Y$, Che Y. Research on Government Logistics Subsidies for Poverty Alleviation with Non-uniform Distribution of Consumers. Omega. 2021; 104:102489. https://doi.org/10.1016/j.omega.2021.102489

13. Tsang YP, Choy KL, Wu CH, Ho GTS, Lam HY, Tang V. An intelligent model for assuring food quality in managing a multi-temperature food distribution centre. Food Control. 2018; 90:81-97. https://doi.org/ https\%3A//doi.org/10.1016/j.foodcont.2018.02.030

14. Feng u, Wang $X$, Duan $Y$, Zhang J, Zhang X. Applying blockchain technology to improve agri-food traceability: A review of development methods, benefits and challenges. Journal of Cleaner Production. 2020; 260:121031. https://doi.org/10.1016/j.jclepro.2020.121031

15. Lean HH, Huang W, Hong J. Logistics and economic development: Experience from China. Transport Policy. 2014; 32:96-104. https://doi.org/10.1016/j.tranpol.2014.01.003

16. Yang C, Lan S, Tseng M-L. Coordinated development path of metropolitan logistics and economy in Belt and Road using DEMATEL-Bayesian analysis. International Journal of Logistics Research and Applications. 2019; 22(1). https://doi.org/10.1080/13675567.2018.1439907

17. Liu G, Hu J, Yang Y, Xia S, Lim MK. Vehicle routing problem in cold Chain logistics: A joint distribution model with carbon trading mechanisms. Resources, Conservation and Recycling. 2020; 156:104715. https://doi.org/10.1016/j.resconrec.2020.104715

18. Rodrigues AC, Martins RS, Wanke PF, Siegler J. Efficiency of specialized 3 PL providers in an emerging economy. International Journal of Production Economics. 2018; 205:163-178. https://doi.org/10.1016/j. ijpe.2018.09.012

19. Defraeye T, Verboven $P$, Opara UL, Nicolai B, Cronjé P. Feasibility of ambient loading of citrus fruit into refrigerated containers for cooling during marine transport. Biosystems Engineering. 2015; 134:20-30. https://doi.org/10.1016/j.biosystemseng.2015.03.012

20. Dao V, Jin I, Hur H, Choi H. Comparison between Water and N-Tetradecane as Insulation Materials through Modeling and Simulation of Heat Transfer in Packaging Box for Vaccine Shipping. Clean Technology. 2016; 22(1):45-52.

21. Li X, Yang L, Duan Y, Wu Z, Zhang X. Developing a Real-time Monitoring Traceability System for Cold Chain of Tricholoma matsutake. Electronics. 2019; 8(4):423. https://doi.org/10.3390/ electronics8040423

22. Zhang S, Chen N, Song X, Yang J. Optimizing decision-making of regional cold chain logistics system in view of low-carbon economy. Transportation Research Part A: Policy and Practice. 2019; 130:844857. https://doi.org/10.1016/j.tra.2019.10.004

23. Jung $\mathrm{H}$, Choi $\mathrm{H}$. Strategies for Korean Companies to Advance into Vietnam's Cold Chain market and ways to activate exports. The e-Business Studies. 2019; 20(4): 285-298. https://doi.org/10.20462/ TeBS.2019.8.20.4.285

24. Yulseong K. Ways for Domestic Logistics Enterprises to Enter the New Logistics Market. Journal of Shipping and Logistics. 2020; 31(3):643-661

25. Qin X, Tian H. Comprehensive evaluation of cold chain logistics level of agricultural products in China based on grey cluster analysis (in Chinese). Preservation and Processing. 2019(5):170-177.

26. Park J. A study on global cold chain logistics-hub determining factors of location based on AHP Analysis-Focus on fresh food product-. Korea Logistics Review. 2017; 27(6):59-70.

27. Ikegawa $M$, Tokunaga $S$. Location choice for Japanese frozen food industry in East Asia using domestic market access with the penetration rate of refrigerators. The Annals of Regional Science. 2018; 61 (1):209-227. https://doi.org/10.1007/s00168-018-0865-6

28. Zhang J, Pang H. Cold chain logistics supply and distribution technology in developed countries (in Chinese). World Agriculture. 2016:179-182. 
29. Wang $M$, Wang $Y$, Liu W, Ma Y, Xiang L, Yang Y, et al. How to achieve a win-win scenario between cost and customer satisfaction for cold chain logistics? Physica A: Statistical Mechanics and its Applications. 2021; 566(15):125637. https://doi.org/10.1016/j.physa.2020.125637

30. Theeb NA, Smadi HJ, Al-Hawari TH, Aljarrah MH. Optimization of vehicle routing with inventory allocation problems in Cold Supply Chain Logistics. Computers \& Industrial Engineering. 2020; 142:106341. https://doi.org/10.1016/j.cie.2020.106341

31. Wells JH, Singh RP. A quality-based inventory issue policy for perishable foods. Journal of Food Processing and Preservation. 1989; 12 271-292.

32. $\mathrm{Li} \mathrm{G}$. Development of cold chain logistics transportation system based on $5 \mathrm{G}$ network and Internet of things system. Microprocessors and Microsystems. 2021; 80:103565. https://doi.org/10.1016/j.micpro. 2020.103565

33. Qi L, Xu M, Fu Z, Mira T, Zhang X. C2SLDS: A WSN-based perishable food shelf-life prediction and LSFO strategy decision support system in cold chain logistics. Food Control. 2014; 38:19-29. https:// doi.org/10.1016/j.foodcont.2013.09.023

34. Zhang W, Zhang X, Zhang M, Li W. How to Coordinate Economic, Logistics and Ecological Environment? Evidences from 30 Provinces and Cities in China. Sustainability. 2020; 12(3):1058. https://doi. org/10.3390/su12031058

35. Tian Y, Wang L. Mutualism of intra- and inter-prefecture level cities and its effects on regional socio-economic development: A case study of Hubei Province, Central China. Sustainable Cities and Society. 2019; 44:16-26. https://doi.org/10.1016/j.scs.2018.09.033

36. Gao Y, Chang D, Fang T, Luo T. The Correlation between Logistics Industry and Other Industries: An Evaluation of the Empirical Evidence from China. The Asian Journal of Shipping and Logistics. 2018; 34 (1):27-32. https://doi.org/10.1016/j.ajsl.2018.03.004

37. Saidi S, Mani V, Mefteh H, Shahbaz M, Akhtar P. Dynamic linkages between transport, logistics, foreign direct Investment, and economic growth: Empirical evidence from developing countries Transportation Research Part A: Policy and Practice. 2020; 141:277-293. https://doi.org/10.1016/j.tra.2020.09.020

38. Magazzino $\mathrm{C}$, Mele M. On the relationship between transportation infrastructure and economic development in China. Research in Transportation Economics. 2020. https://doi.org/10.1016/j.retrec.2020. 100947

39. Andersson DE, Andersson ÅE. Infrastructural change and secular economic development. Technological Forecasting and Social Change. 2008; 75:799-816. https://doi.org/10.1016/j.techfore.2007.08.003

40. Lai Z, Ge D, Xia H, Yue Y, Wang Z. Coupling coordination between environment, economy and tourism: A case study of China. PloS One. 2020; 15(2). https://doi.org/10.1371/journal.pone.0228426 PMID: 32017789

41. Akbara $\mathrm{YH}, \mathrm{McBride} \mathrm{JB}$. Multinational enterprise strategy, foreign direct investment and economic development: the case of the Hungarian banking industry. Journal of World Business. 2004; 39(1):89105. https://doi.org/10.1016/j.jwb.2003.08.001

42. Dong $F$. The impact of economic openness on standard of living and income inequality in eight countries. Emerging Markets Review. 2014; 21:234-264. https://doi.org/10.1016/j.ememar.2014.09.005

43. Wang Z, Asghar MM, Zaidi SAH, Nawaz K, Wang B, Zhao W, et al. The dynamic relationship between economic growth and life expectancy: Contradictory role of energy consumption and financial development in Pakistan. Structural Change and Economic Dynamics. 2020; 53:257-266. https://doi.org/10. 1016/j.strueco.2020.03.004

44. Bresolin CS, Schneider PS, Rego R, Filho EPB. Brazilian cold chain panorama. International Journal of Refrigeration. 2018; 90:145-155. https://doi.org/10.1016/j.jjrefrig.2018.04.002

45. Raut RD, Gardas BB, Narwane VS, Narkhede BE. Improvement in the food losses in fruits and vegetable supply chain-a perspective of cold third-party logistics approach. Operations Research Perspectives. 2019; 6:100117. https://doi.org/10.1016/j.orp.2019.100117

46. Rossi T, Pozzi R, Pirovano G, Cigolini R, Pero M. A new logistics model for increasing economic sustainability of perishable food supply chains through intermodal transportation. International Journal of Logistics Research and Applications. 2020. https://doi.org/10.1080/13675567.2020.1758047

47. James SJ, James C, Evans JA. Modelling of food transportation systems-a review. International Journal of Refrigeration. 2006; 29(6):947-957. https://doi.org/10.1016/j.ijrefrig.2006.03.017

48. Ndraha N, Sung W-C, Hsiao H-I. Evaluation of the cold chain management options to preserve the shelf life of frozen shrimps: A case study in the home delivery services in Taiwan. Journal of Food Engineering. 2019; 242:21-30. https://doi.org/10.1016/j.jfoodeng.2018.08.010

49. G€oransson $M$, Nilsson $F$, Jevinger $\AA$. Temperature performance and food shelf-life accuracy in cold food supply chains-Insights from multiple field studies. Food Control. 2018; 86:332-341. https://doi.org/ 10.1016/j.foodcont.2017.10.029 
50. Bogataj M, Bogataj L, Vodopivec R. Stability of perishable goods in cold logistic chains. International Journal of Production Economics. 2005; 93-94:345-356. https://doi.org/10.1016/j.ijpe.2004.06.032

51. Derens-Bertheau E, Osswald V, Laguerre O, Alvarez G. Cold chain of chilled food in France. International Journal of Refrigeration. 2015; 52:161-167. https://doi.org/10.1016/j.jrefrig.2014.06.012

52. Montanari R. Cold chain tracking: a managerial perspective. Trends in Food Science \& Technology. 2008; 19(8): 425-431. https://doi.org/10.1016/j.tifs.2008.03.009

53. Shannon CE. A mathematical theory of communication. The Bell System Technical Journal. 1948; 27 (3):379-423. https://doi.org/10.1002/j.1538-7305.1948.tb01338.x

54. Zhang Z, David J. An entropy-based approach for assessing the operation of production logistics. Expert Systems with Applications. 2019; 119:118-127. https://doi.org/10.1016/j.eswa.2018.10.044

55. Lin Z, Wen F, Huang J, Zhou H. Evaluation of Black-Start Schemes Employing Entropy Weight-Based Decision-Making Theory. Journal of Energy Eneingeering. 2010; 136(2):42-49. https://doi.org/10.1061/ (ASCE)EY.1943-7897.0000023

56. Lana SL, Zhong RY. Coordinated development between metropolitan economy and logistics for sustainability. Resources, Conservation and Recycling. 2018; 128: 345-354. https://doi.org/10.1016/j. resconrec.2016.08.017

57. Zuo Z, Guo H, Cheng J, Li Y. How to achieve new progress in ecological civilization construction?Based on cloud model and coupling coordination degree model Ecological Indicators. 2021; 127:107789. https://doi.org/10.1016/j.ecolind.2021.107789

58. Hao J, Zhang L, Liu L. Coupling Relationship of Freight Transportation Activities and Transport Infrastructure: Case Study of Yunnan, China. Journal of Urban Planning and Development. 2020; 146(4). https://doi.org/10.1061/(asce)up.1943-5444.0000603

59. Kong Y, Liu J. Sustainable port cities with coupling coordination and environmental efficiency. Ocean and Coastal Management. 2021; 205(1):105534. https://doi.org/10.1016/j.ocecoaman.2021.105534

60. Fan W, Wang H, Liu Y, Liu H. Spatio-temporal variation of the coupling relationship between urbanization and air quality: A case study of Shandong Province. Journal of Cleaner Production. 2020; 272:122812. https://doi.org/10.1016/j.jclepro.2020.122812

61. Sun $\mathrm{Y}$, Cui $\mathrm{Y}$, Huang H. An Empirical Analysis of the Coupling Coordination among Decomposed Effects of Urban Infrastructure Environment Benefit: Case Study of Four Chinese Autonomous Municipalities. Mathematical Problems in Engineering. 2016; 16:1-11. https://doi.org/10.1155/2016/8472703

62. Deng J. Control problems of grey systems. Systems \& Control Letters. 1982; 1(5):288-294. https://doi. org/10.1016/S0167-6911(82)80025-X

63. Wang S, Wei C. Demand Prediction of Cold Chain Logistics Under B2C E-Commerce Model. Journal of Advanced Computational Intelligence and Intelligent Informatics. 2018; 22(7):1082-1087.

64. Chen S, Chen W, Soomro A, Luo L, Xiang W. Multi-objective economic emission dispatch of thermal power plants based on grey relational analysis and analytic hierarchy process. Energy \& Environment. 2019; 31(5):785-812. https://doi.org/10.1177/0958305x19882387

65. Yin H, Liu B, Zhang H. A New Computation Model of Incidence Degree Met Four Axioms of Grey Incidence (in Chinese). Henan Science. 2006; 24(2):162-165.

66. Feng $\mathrm{X}$, Chen $\mathrm{Q}, \mathrm{Yao} \mathrm{H}$. Statistical analysis of the relationship between logistics industry development and economic growth. International Conference of Logistics Engineering and Management. 2010:4144-4147.

67. Gao Y, Zhang Y, Li H, Peng T, Hao S. Study on the Relationship Between Comprehensive Transportation Freight Index and GDP in China. Procedia Engineering. 2016; 137:571-580. https://doi.org/10. 1016/j.proeng.2016.01.294

68. Toorajipour R, Sohrabpour V, Nazarpour A, Oghazi P, Fischl M. Artificial intelligence in supply chain management: A systematic literature review. Journal of Business Research. 2021; 122:502-517. https://doi.org/10.1016/j.jbusres.2020.09.009 